\title{
新鮮な石炭の常温空気酸化の ESRによる研究
}

（昭 和 43 年 2 月 28 日受理）

大内 日出夫*1 塩 谷 優 ${ }^{* 2}$ 相 馬 純 吉*2

炭鉱に怙ける炭層の自然発火と炭じん爆発の防止を目的として，新鮮な石炭が常温空気酸化を受けた場合の遊離基の挙動をESR スペクトルの変化から考察した。できるだけ空気に触れないようにして採取された石炭試料の ESRを観測し，その試料に空気を 接触させることによって生ずる ESR スペクトルの变化を追跡した。この ESR スペクトルの変化を解析し，石炭の常温空気酸化 過程を考察して, 次の結論を得た。

（1）石炭の磁気中心濃度は，石炭化の進んだ石炭ほど高い。（2）新鮮な石炭は常温の空気と接触すると，その遊離基濃度を增 加させる。この濃度增加量は低石炭化炭ほど大きい。（3）新鮮な石炭の ESR シグナルの線幅は空気と接触後も不变であった。 （4）新鮮な石炭の常温空気酸化は，遊離基のスピンー格子緩和時間には大きな影響を与えず，石炭中に化学变化を起こしていると 考えられる。（5）新鮮な石炭が空気に接触後，増加する迶離基の量は，石炭の炭素含有率の増加とともに減少し，酸素含有率と ともに增加する。（6）ESR スペクトルを与える磁気中心には，石炭内に 2 種類あると考えられるが，空気接触後に生成増加する 磁気中心は縮合した芳香族環状化合物の欠陥ではなく，石炭中の外側基群の成分が酸素と反応することによって生成された遊離基 であろうと推測される。

\section{1 粕言}

炭層の自然発火あるいは炭じん爆発に，その反応の中間体とし ての遊離基が関与することは, 多くの有機物の反応から類推して 当然考兄られることである。自然発火扣よび炭じん爆発防止のた めに, 酸化過程の遊離基の挙動を研究する必要がある。

石炭中の遊離基がどのよ 5 に存在し，反応過程でいかなる役割 を演してているかと言うことは，石炭自身の構造のあいまいさと相 まって未だはっきりしていない。石炭類の遊離基に関する研究は 約十数年前から始められたばかりで，反応過程の本質を究明する には至っていない。むしろ，石炭の構造あるいは性質を遊離基の 挙動から解明しようとしているのが現状である。

石炭類の電子スピソ共鳴に関する研究は, Uebersfeld $5^{1)}$ Ingram $5^{2)}$ の先駆者的業績以来, 豊田 $5^{3 \sim 6)}$, Singer $5^{7)}$ に って, 短期間に非常に多くの業績が積み重ねられつつある。しか し，これらの業續は，いずれも空気に長時間接触した後の石炭に 関する研究であり，空気に触れない石炭中の遊離基，あるいは空 気に接触することによる石炭中の遊離基の変化については何の知 見をも与兄ない。しかも，炭層の自然発火あるいは炭じん爆発の 現象で, 空気に触れていない新鮮な石炭が空気に触れることによ って起こる石炭の初期酸化過程は，それらの発生初期段階に拉い てきわめて重要なるのである。

著者らは，この石炭の常温に就ける空気酸化過程を解明するた

*1 Hideo OHUCHI 北海道大学工学部鉱山工学教室 : 現在, 資源技術試験所北海道支所：札幌市白石町平和通 3 丁目.

*2 Masaru SHIOTANI, Junkichi SOHMA 北海道大学工学部 合成化学工学教室: 札幌市北 12 条西 8 丁目.

1) J. Uebersfeld, A. Eienne, J. Combrison, Nature, 174, 614 (1954).

2) D. J. E. Ingram, J. G. Taplay, R. Jackson, R. L. Bond, A. R. Murnaghan, Nature, 174, 797 (1954).

3) H. Honda, K. Egi, S. Toyoda, Y. Sanada, T. Furuta, Carbon, 1, 155 (1964).

4）豊田貞治，本田英昌，燃協，44，697（1965).

5）豊田貞治, 燃協, 45, 422（1966）.

6）豊田貞治，菅原幸子，本田英昌，燃協，45，876（1966).

7) L. S. Singer, "Proceedings of the Fifth Carbon Conference", Vol. 2, 37 (1963).
めに, 空気に触れていない新鮮な石炭の ESR スペクトルを観測 し,さらにこのスペクトルの空気と接触後の変化を追跡した。そ の実験に基づいて，石炭の空気酸化過程を考察した。

\section{2 実験}

\section{$2 \cdot 1$ 石炭試料採集之 ESR 実験試料}

石炭試料採集個所と石炭の元素分析值を表 1 に示す。採取個所 は各炭坑のできるだけ地山部分の炭壁を選び、ピック等で炭壁を 約 $50 \mathrm{~cm}$ 掘って，2〜10 cm 程度の小塊炭を市販の水枕にできる だけ早く入れてその栓をした。水枕の水は溶存酸素の除去された 蒸留水である。

表 $1 \mathrm{ESR}$ 実験試料

\begin{tabular}{|c|c|c|c|c|c|}
\hline 試 料 採 集 简 所 & 水分 & 戻分 & $\mathrm{C}^{*}$ & $\mathrm{H}^{*}$ & $\mathbf{O}^{*}$ \\
\hline 三菱大夕張夕張夾㛶層下層奥部南 1 片沿層 & 1.0 & 9.6 & 85.4 & 6.3 & \\
\hline 三井砂川奥奈井江坑異人沢部内 3 番層引立 & 2.4 & 18.0 & 78.0 & 5.2 & 15.7 \\
\hline 太平洋沼尻号本層ロング & 5.0 & 10.2 & 76.1 & 6.4 & 16.3 \\
\hline 羽幌笨別坑右 7 片払築別東翼本層" & 7.6 & 9.3 & 76.0 & 6.0 & 15.9 \\
\hline 北拓小石南坑 3.5 片 1 番層立入 & 14.6 & 13.0 & 70.6 & 5.5 & 22.9 \\
\hline
\end{tabular}

* 元素分析值 (無水無分ベース)

実験試料の作成は次のよ 5 にす る。坑内から石炭をもら帰った後, 水枕に入れた石炭をできるだけ手早 く濡れたままとり出す。あらかじめ 窒素ガスで置換されたドライボック スの中へ石炭をできるだけ早く入れ る。塊状の石炭をボックス内で真空 乾燥し, 次いでボックス内に窒素ガ スを入れ常圧にもどす。窒素ガス充 填のボックスの中で石炭を 28〜48 メッシュに破砕する。粉砕した石炭 をボックス内で, 図1のよ5なサン プルチューブに入れ，コックBを閉 じて，石炭を空気に触れさせないで 真空系に $A$ 部のすり合わせで接続す る。その後, コックBを開いて脱気 乙, 約 1 昼夜真空度 $10^{-5}$ Torr に保 ち，図1のC部で溶封する。
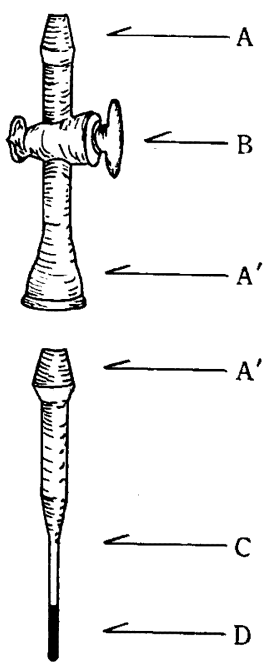

図 1 サンブルチューブ $A, A^{\prime}$ ：共通すり合せ， B : コっク， C : 熔断簓所, D : 石扊試料 $(0.4$ $\sim 0,8 \mathrm{~g}$ ) 
このよ5にして調製された石炭試料は，空気に触れていない石 炭と考えることができる。この実験では, 空気に触れていないと 考えられる石炭を“新鮮な石炭”と呼ぶ。さらに新鮮な石炭を空 気に接触させるときには試料管の溶封を破って空気を導入した。

\section{$2 \cdot 2$ ESR 測定装置と測定方法}

ESR の測定には，日本電子製 $3 \mathrm{BX}-\mathrm{ESR}$ スペクトロメーター を用いた。ESR 測定温度は室温 $\left(18 \sim 21^{\circ} \mathrm{C}\right)$ である。磁気中心 の濃度測定には，ESR 飽和現象の起こらない範囲のマイクロ波 出力（本装置では $16 \mathrm{db}$ ) を常用した。図的積分で得た面積は遊 離基濃度に比例する量であるので，標準物質 DPPH の面積と対 比して石炭中の全磁気中心濃度を求めた。単位重量当りの絶対濃 度 $\left(\mathrm{N}_{\mathrm{R}} / \mathrm{g}\right.$-Coal) は, サンプルチュープの内径, サンプル重量, サンプルの真比重および灰分含有率等の補正を行なって求めた。

石炭の ESR 飽和効果の観測は，小さなマイク口波出力から溂 次出力を上げ, 微分吸収曲線のピークの高さの減少を目安として 行なった。常温空気酸化に伴 5 遊離基濃度の変化を追跡するため に, 新鮮な石炭の真空中での磁気中心濃度を計測したのち, 空気 をサンプルテューブ内に導入し, 所定の時間ごとに ESR スペク トルを観測した。

\section{3 測 定 結 果}

\section{$3 \cdot 1$ 磁気中心濃度と線幅}

新鮮な石炭の ESR スペクトルと, 空気酸化後のスペクトルの 経時変化の代表例を図 2 亿示す。いずれの炭種についても，ESR スペクトルは, 線幅が 8〜9 gauss の単純な一本線である。この 図例で示されるよ5に，新鮮な石炭の ESR スペクトルの線幅は， 空気酸化を受けた石炭で観測される ESR スペクトルの線幅とほ そんど相違がない。この空気酸化によって線幅が影響されないと 言う事央は各炭種について共通であった。 $\Delta H_{1 / 2} / \Delta H_{\mathrm{ms} 1}$ 值も空気 酸化による変化が認められなかった。各炭種によって, 若干の相 違はあるが, $\Delta H_{1 / 2} / \Delta H_{\mathrm{ms} 1}$ 值は $1.39 \sim 1.47$ である。ガウス型の 理論値は 1.18 であるから, 実験された総ての石炭の ESR スペ クトルはガウス型とローレンシ型の中間である。

ESR スペクトルから求めた磁気中心濃度の空気酸化による変 化を各炭種別に図 3 に示す。図 3 に示す事実をまとめると次のよ らになる。

1）新鮮な石炭の磁気中心濃度は, 石炭化の進んだ石炭ほど大

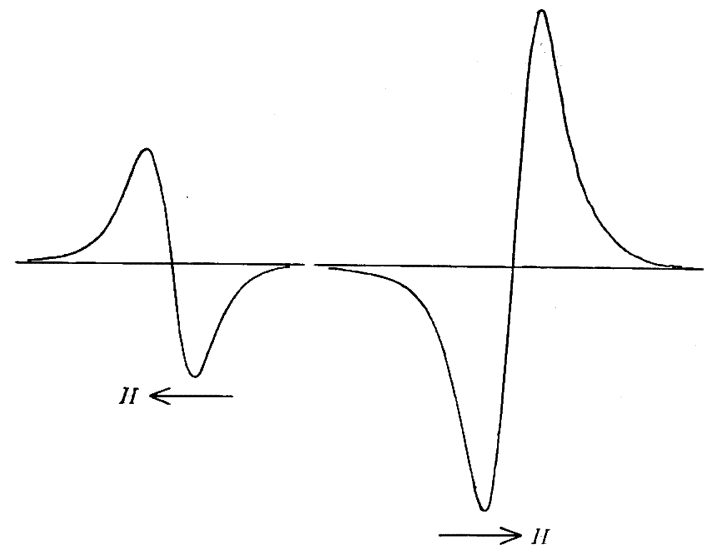

(a)

(b)

図 2 新鮮な石炭の常温空気酸化による ESR シグナル変化 (a): 北拓小石炭, 真空中, $28 \sim 48$ メッシュ, 常温 (b) : 同上，空繁酸化後 $30 \mathrm{~min}$
である。これは豊田 ら特よび Smidt ら の観測事実とよく一致 している。

2）新鮮な石炭では 酸化によって遊離基濃 度が增加する。その増 加割合は，石炭化が進 むにつれて少なくなる 傾向にあった。

\section{2 石炭の ESR 飽} 和現象

図4のよ5に; 横軸 にマイクロ波減衰器の 読みの平方根をとり， 緃軸に ESR スペクト ルの強度をとる。マイ クロ波の発振している クライストロンの出力 は，近似的に一定と考 えてよいからこの読 みが大さいほど、試料 に入射するマイクロ波 のエネルギーは小ざ い。真空中では, 石炭 化の進んだ石炭ほど館 和しやすくなる傾向が 認められた。空気中で は, 大夕張炭だけが真 空中のそれに比べて若 干飽和しにくくなる傾 向にあった。

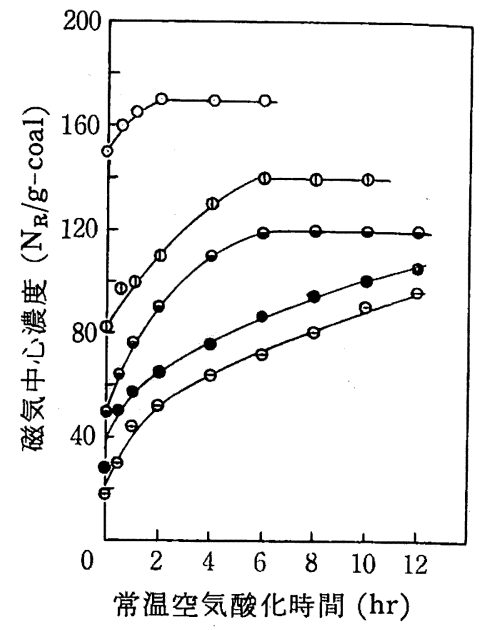

図 3 常温空気酸化時間と磁気中心濃度 $\bigcirc$ : 大夕張炭, (1) : 砂川炭, $\ominus$ : 築别炭 : 太平洋炭, $\ominus$ : 小石炭

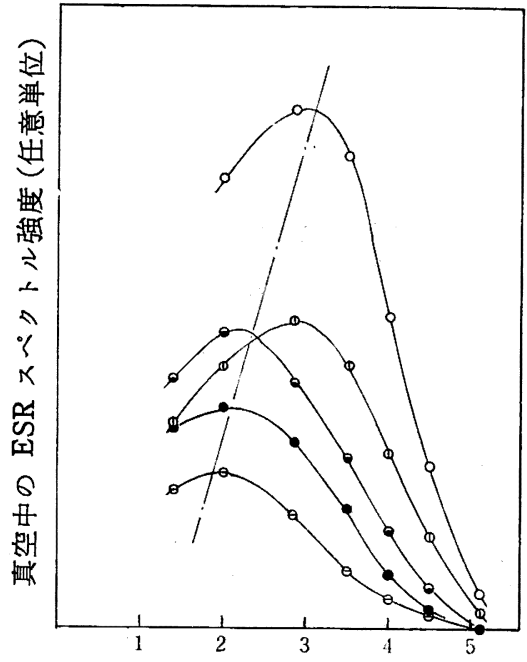

マイクロ波減衰器の読みの平方根 $(\mathrm{db})^{1 / 2}$

因 4 石炭の ESR 飽和曲線 （記号は図3に同し）

\section{4 考察}

\section{$4 \cdot 1$ 新鮮な石炭中に存在する磁気中心}

空気に触れていない新鮮な石炭から ESR スペクトルが観測さ れる事実は，石炭中には当然なんらかの磁気中心，この場合は不 対電子が存在することを意味している。石炭中の不対電子として は，黑鉛的な大きな縮合環状化合物中の欠陷1,2)，山るいは石炭中 に天然に捕捉されている遊離基, この二つの可能性が考えられる。 新鮮な石炭から観測される ESR スペクトルは単純な一本線でな んの構造も示さないので, ESR スペクトルからは，そのいずれ とも判定し難い。

しかし, 石炭のピリジン抽出物からも一本線の ESR スペクト ルが観測され，またピリジンで抽出されない残分からも，構造を 持たない一本線の ESR スペクトルが観測された9)。ピリジンで 石炭から抽出される物質は比較的低分子量のものであり，4環以 上の環状化合物は含まれないことが見い出されている10)。したが

8) J. Smidt, D. W. van Krevelen, Fuel, 38, 355 (1959),

9）相馬純吉, 塩谷 優, 未発表.

10）横山 晋, 私信, 
って，石炭のピリジン抽出物から钼測される ESR スペクトルは， 比較的低分子の遊離基に由来するものである。一方，ピリジン残 分が示す ESR スペクトルは 5 環以上の縮合多環化合物に帰せら れるべきものであり，その中には黒鉛的な大きな縮合環状化合物 も含まれていると考えるのが自然であろら。

上述の事実は，石炭中には低分子の遊離基と黒鉛棈造に似た多 環縮合化合物に由来する不対電子の 2 種類の磁気中心が共存して いることを示していると考えるのが妥当であろう。

\section{$4 \cdot 2$ 常温空気酸化による石炭中の磁気中心濃度の变化}

新鮮な石炭は，常温で空気酸化を受けると磁気中心が増加する と言う事実が確認された。従来の石炭類の研究成果によれば11 13)，常温での酸素の影響は，吸収線の線幅のブロードニングとし て観測されることが報告されている。これは，酸素の常磁性のた め, スピンー格子緩和時間 $T_{1}$ が減少し，そのため線幅が増加す るものと解釈されている。この場合，酸素の影響は物理的なもの である。

新鮮な石炭を試料とした本実験では，酸素の導入によっても， 線幅の增加は見られず，ESR 強度だけが増加することが観測さ れた。このような従来の観測結果との不一致は, 従来の観測は新 鮮でない試料を用い，この実験では新鮮な石炭を試料として用い たためと考兄られる。すなわち，新鮮な石炭では，常温酸化初期 に酸化性に富む反応表面があることを暗示している。また，図 3 で示されるように, 約 12 時間後にはこの遊離基の増加が飽和す る傾向にある。従来の観測は，この酸化性に富む反応表面が完全 に覆われてしまった後の試料についての観測であり，そのため酸 化による遊離基の増加は認められず，物理的な緩和時間への影響 のみが観測されたものと思われる。

空気と接触後の石炭の ESR 強度の増加は, 新鮮な石炭が酸化 され，その結果磁気中心となる不対電子が増加したためである。 したがって，この常温空気酸化による ESR 強度の増加は, 石炭 の酸化性の目安と見ることができる。

石炭の常温に批ける酸化性は，石炭の磁気中心濃度とは無関係 である。このことは, 図 3 で示されるよ5に，新鮮な石炭で始め の磁気中心濃度の高い炭種はかえって, 酸化にょる ESR 強度の 増加が少ないことでも示される。また，この事実は，石炭化の進 んだ石炭ほど，酸化雾囲気に打ける酸素消費量が少ないと言うこ

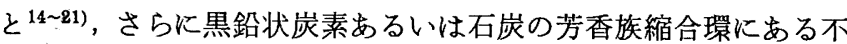

11) J. Uebersfeld, E. Erd, "Proceedings of the Third Carbon Conference" (1959) p. 103.

12) D. J. E. Ingram, "Proceedings of the Third Carbon Conference" (1959) p. 93.

13) E. de Ruiter, Fuel, 41, 63(1962); Fuel, 44, 45(1965).

14）松本敬信，中村 昌二，北鉱，13，201（1957）；14，181 (1958).

15）古谷敏夫, 渡辺伊温, 石橋一二, 北鉱, 17, 155, 206(1961)

16）中野貫一, 栗原一雄, 中村昌二, 菊地 昭, 採鉣々保安, 11, 505 (1965).

17) B. K. Mazumdar, S. K. Chakrabartty, (MRS) M. Saha, K. S. Anand, A. Lahri, Fuel, 38, 469 (1959).

18) J. N. Bhowmik, P.N. Muknerjee, A. Lahri, Fuel, 38 , 211 (1959).

19) P. G. Sevenster, Fuel, 40, 1 (1961).

20) P. B. Conrow, R. A. Durie, J. S. Shannon, S. Sternhell, Fuel, 42, 275 (1963)

21) D. L. Carpenter, D. G. Giddings, Fuel, 43, 247, 375 (1964).
対電子は酸化され難く，酸素と物理的相互作用をなするのと考兄 られていること1,2) とを併せ考えれば，新鮮な石炭で観測される ESR スペクトルは，大部分芳香族性の縮合環中の久陷に由来す るものと考觉らる。

Antonowicz $\left.{ }^{22}\right)$ によれば，高温 $\left(800^{\circ} \mathrm{C}\right)$ でのカーボンの酸化過 程には，磁気中心をつくる生成機構と磁気中心を減少させる消隇 機構とがあるとされている。すなわち, 酸化によって黒鉛的な炭 素の微結晶の炭素がうばわれ，その跡に不対電子を含む一種の “imperfection”が生ずれば, カーボンの結晶子中に一種の欠陷が 生じて ESR で観測される磁気中心となる。また，炭素原子の “local surface diffusion”すなわち原子の再配列が起これば，不 対電子を含むカーボン表面での欠陥が消滅するので, 磁気中心は 減少する。石炭中にはかなり大きい縮合芳香族化合物の存在が知 られて沶り，この大きい縮合芳香族化合物を近似的には黒鉛的と 見なし得るので，空気と接触後，上述の Antonowicz の生成機 構によって, 磁気中心が増加し，ESR 強度が増加して観測され ることが考吕れる。もし，この機構によって ESR 強度が増加 すれば，遊離基濃度の増加は縮合芳香族性と比例するはずである。 図 5 は常温空気酸化による遊離基増加量を石炭の炭素含有率に対 してプロットしたものである。空気に接触以前の遊離基量と, 空 気導入後 12 時間の遊離基量との差を遊離基増加量とした。ただ し, 大夕張炭と砂川炭は早く飽和するので, 初期量と飽和時の遊 離基量との差を遊離基增加量とした。この図に示されるように, 常温空気酸化による遊離基増加量 $\Delta N_{\mathrm{R}}$ は，炭素含有率が高まる につれて少なくなる。こ のことは，上述の予想と 反対であり，新鮮な石炭 の空気酸化による遊離基 增加が Antonowicz 機構 によるものではないこと を示している。

図 6 は, 常温空気酸化 による遊離基の増加量 $\Delta N_{\mathrm{R}}$ と石炭中の 酸素含 有率との関係を表わした ものである。図 7 は石炭 の炭素原子数と酸素原子 数との比 $\mathrm{O} / \mathrm{C}$ に対して,

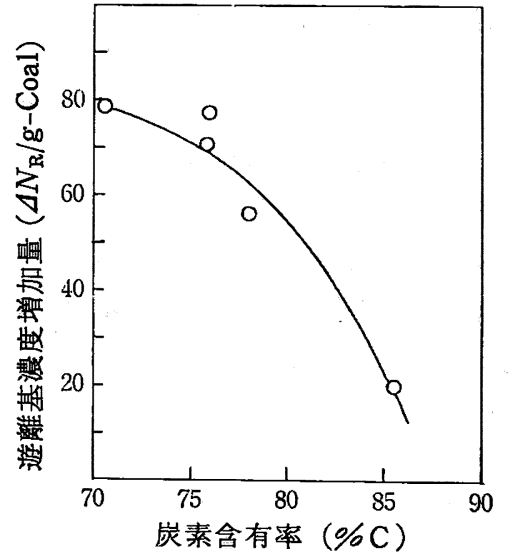

図 5 遊離基濃度增加量と炭素含有率 (d. a.f)

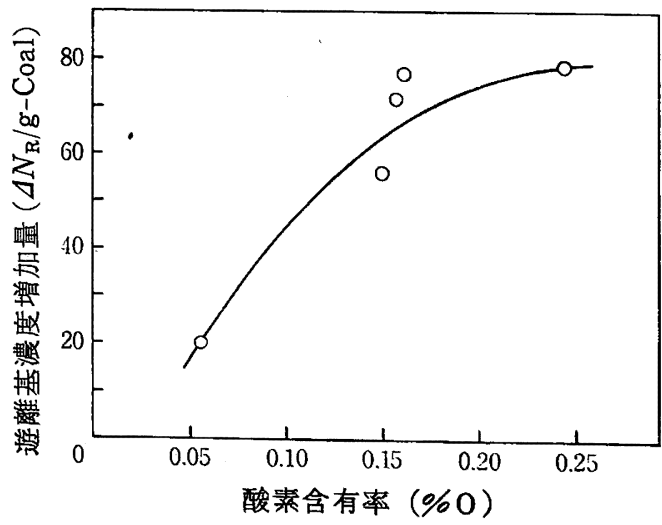

図 6 遊離基濃度增加量と酸素含有率 (d.a.f)

22) K. Antonowicz, J. Chem. Phys., 36, 2046 (1962). 


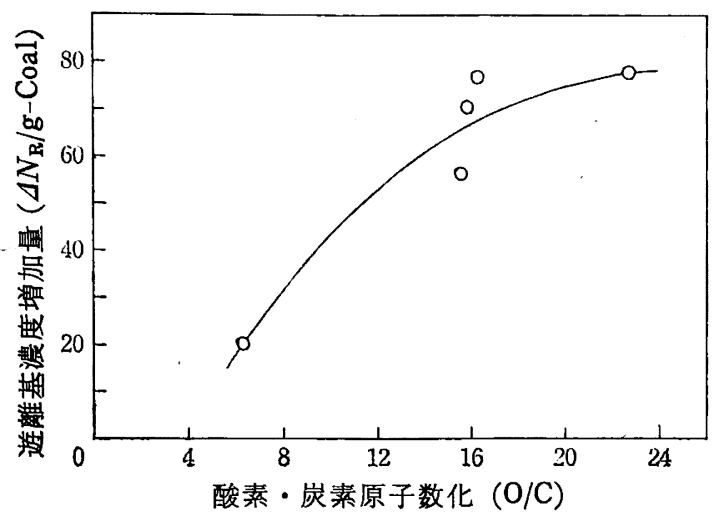

図 7 遊離基濃度增加量と $\mathrm{O} / \mathrm{C}$ 值

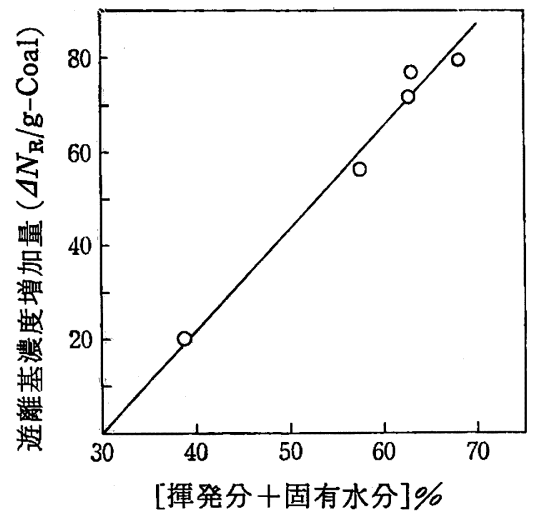

図 8 遊離基濃度増加量と [揮発分十固有水分] (a.f)

$\Delta N_{\mathrm{R}}$ をプロットしたものである。 $\Delta N_{\mathrm{R}}$ は $\mathrm{O} / \mathrm{C}$ 值とともに増加 している。図 6 および図 7 で表わされる事実は, いずれも, 常温 空気酸化による磁気中心の増加はAntonowicz 的な機構によるも のでないと言 5上述の考察を支持している。

図 8 は $\Delta N_{\mathrm{R}}$ が石炭中の揮発分と固有水分との総和に対して, どのように変化しているかを示す。同図に示されるよ5に，両者 は直線的な関係にあることが見い出された。石炭の芳香族縮合環 数がその炭素含有率 85〜87\% 位までほとんど変化しない23にも かかわらず, 図5のよ5な関係があることは, 石炭の常温空気酸 化によっては, 酸素が芳香族環に直接結びつかなかったことを示 すものである。石炭の酸化温度 $170 \sim 180^{\circ} \mathrm{C}$ 以下では, ほとんど 芳香族縮合環の酸化は行なわれず，脂肪属または脂環属の部分に 牤いてのみ反応が起こるとされている ${ }^{17,18,20,24)}$ これらの事実も 新鮮な石炭の常温空気酸化による遊離基增加が揮発分および固有 水分と関連して起こると言うことと同じ傾向にある。

上述した一連の事実は，新鮮な石炭の常温空気酸化による遊離 基濃度の増加が新鮮な石炭の芳香族的な部分で行なわれるのでは なく，その揮発分挌よび水分に含まれる含酸素基あるいは側鎖部 分の酸化による遊離基生成が原因であることを示している。

一方, 石炭の電気伝導に関する研究によれば25)，炭素含有率 85 87\% 以下の炭種に拈いて，石炭の電気伝導のキャリャーの 易動度は，芳香族的な部分よりも芳香族縮合環の周辺に存在する 直鎖状部分または含酸素部分で主として支配されることが示され

23）馬場有政, 照井秋生, 本田英昌, “石炭化学工業”, 産業図 書 (1960) p. 66 .

24）藤井修治, 燃協，38，98（1959）；43，181，821（1964）.

25）大内日出夫, 磯部俊郎, 相馬純吉, 未発表（燃協誌投稿予 定).
た。遊離基の不対電子は電気伝導のキャリヤーともなり得るもの で, ESR を示す不対電子が電気伝導のキャリヤーである可能性 も十分考えられる。この考察によれば, 常温空気酸化で增加する 遊離基は，石炭の揮発分拈よび水分の内，芳香族環の外側にある 部分の酸化によって生成されたものと推測される。外側基群の大 いさ，すなわち含酸素基むるい側鎖等の大いさは固有水分括よび 揮発分の多い低石炭化炭ほど多い26 29)。したがって, 低石炭化炭 ほど, 遊離基濃度増加量が多くなることも上記の考学から理解で きる。

遊離基增加量 $\Delta N_{\mathrm{R}}$ が 0 になる点は, 図 8 で示されるように, 揮発分と固有水分との総和が $30 \%$ になるところである。この值 は炭素含有率に換算して持よそ $90 \% \mathrm{C}$ に相当し，芳香族性が非 常に発達するところである。すなわち，このような高石炭化炭は 常温空気酸化では遊濩基増加を示さず, 酸素に対して化学的に安 定な石炭構造である。この事実も常温空気酸化が芳香族部分で起 こらないと言う考察を支持している。

結局, 石炭には次の二つの種類の活性点, すなわち不対電子が めるものと考えられる。

1）酸素に対して，常温では化学的に安定で，単に吸着等の物 理的相互作用をもち，緩和にのみ影響を与えるるの。これは芳香 族縮合環内にある不対電子であって, 縮合環の発達に伴って, よ り安定に存在しうるようになる。

2）遊離基の不対電子である。これには新鮮な石炭に酸素と接 触する以前から存在していたものと, 酸素と接触後に酸化で生成 されるものとがある。常温で空気酸化によって生成される遊離基 は, 石炭の揮発分および固有水分と密接な関係にあり, 芳香族縮 合環の外側にある含酸素基や側鎖の部分の酸化で生成されるもの と推測される。

\section{5 結 論}

1）空気に触れていない新鮮な石炭から明瞭な ESR スペクト ルが観測された。ESR スペクトルを示す磁気中心としては，黒 鉛的な芳香族縮合環中の欠陷と, 遊離基の双方が石炭中に共存し ている。

2）新鮮な石炭を常温で空気酸化させると，その磁気中心濃度 は増加する。その増加割合は低石炭化炭ほど大きいことが確認さ れた。

3）常温空気酸化の実験範囲内（酸化時間 12 時間）では, 真 空中の新鮮な石炭の ESR スペクトルの線幅と，酸化炭のそれと の間には差は認められない。

4）新鮮な石炭の酸化による遊離基濃度の増加は, 石炭中の炭 素酸素原子数比 $\mathrm{O} / \mathrm{C}$ 值とともに増加する。また, この増加量は 揮発分と固有水分との総和に比例して大きくなる。酸化によって 生成される遊離基は，芳香族縮合環の外側にある含酸素部分また は直鎖状部分によるものと推測される。

26）杉村秀彦, 真田雄三, 燃協, 45, 884 (1966).

27）武谷 愿, 伊藤光臣, 鈴木 章, 横山 晋, 燃協, 43,837 (1964).

28) L. Blom, L. Edelhausen, D. W. van Krevelen, Fuel, 36, 135 (1957).

29）馬場有政, 照井秋生, 本田英昌, “石炭化学工業”, 産業図 書 (1960) p.70. 
本研究にさいして，石炭試料を供与された北拓小石鉱業所，羽 熀築別鉣業所，太平洋釧路炭磺，三井砂川鈗業所並びに三菱大夕 張鉱業所の皆様に梁く謝意を表します。資源技術試豎所北海道
支所長栗原一雄氏，同所第二課長 田代襄氏 には万般にわたり 御配虑を頂き括礼申し上げます。終始御教導を睗わった北海道大 学工学部磯部俊郎教授に心から感謝致します。

\title{
1-ナフトールとジアゾアニリンとの反応速度ならびに異性体の生成割合*1
}

(昭 和 43 年 2 月 12 日 受 理)

\author{
岸本 諭・平島恒亮・真鍋 修・檜山八 郎*2
}

1ーナフトールKジフゾフニリンを作用すると 4-フェニルフゾ-1-ナフトール（4-体色素と略称）と 2-体色素および 2,4-ビス体 色素が生成し，その生成割合は $\mathrm{pH}$ とともに変化した。 $\mathrm{pH}$ が増大するにつれて 4-体色素の生成割合は増加し， $\mathrm{pH}$ が 8 以上では 4一体色素の溶解度が増加するため，2，4-ビス体色素の生成割合が急激に増大した。なお，2,4-ビス体色素は主として4-体色素よ り生成することが明らかとなった。

また，2-体色素怙よび 4-体色素の生成反応の動力学的研究から 2-体色素の生成反応には塩基触媒効果が認められないが，4-体 色素の生成反応ではそれが認められた。

これらの結果より，1-ナフトールの 2-位へのカップリング反応はジフジニウムイオンが 1-ナフトレートイオンを攻撃し，の-コ ンプレックスを形成する段階が律速段階で, 4-位へのカップリング反応は塩基濃度の小なるところではの-コンプレックスよりの 脱プロトン化段階が反応を律速し，塩基濃度が高く $\mathrm{pH}$ が 9 付近以上では，むしろ ることがわかった。

\section{1 緒言}

1-ナフトールにジアソ゚アニリンを作用すると 4 -フェニルアゾー 1-ナフトール（4-体色素と略称）と 2-体色素技よび 2,4-ビス体 色素が生成することは周知のことであるが，その生成割合などに 関しての詳細は不明であるので，これらを明らかにするため， 各 $\mathrm{pH}$ 溶液中での異性体の生成割合ならびに反応速度を測定し， あわせて反応温度による影響も調べ, 活性化エネルギーならびに エントロピーを求めた。

\section{2 実験および計算}

\subsection{2-体，4-体および 2,4-ビス体色素の合成と精製}

2・1・1 2-体色素の合成と精製 純粋な 1,2 -ナフトキノンとフ

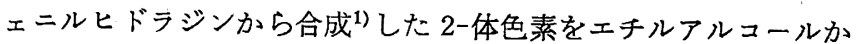
ら 2 回再結晶して純粋な 2-体色素 \{分析値: $\mathrm{C}=77.4 \%, \mathrm{H}=5.0$ $\%, \mathrm{~N}=11.0 \%$ (計算值 : $\mathrm{C}=77.4 \%, \mathrm{H}=4.8 \%, \mathrm{~N}=11.3 \%$ )\}, $\mathrm{mp} 139^{\circ} \mathrm{C}$ を得た。

2.1.2 4-体色素の合成と精製 純粋な 1,4 -ナフトキノンとフ

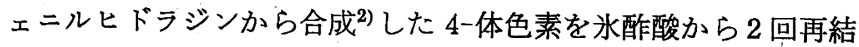
晶して純粋な 4-体色素 \{分析値：C=77.2\%， H=4.8\%， N= $11.2 \%$ (計算值 : $\mathrm{C}=77.4 \%, \mathrm{H}=4.8 \%, \mathrm{~N}=11.3 \%$ ) \}, mp 206 ○吕を得た。

2・1・3 2,4-ビス体色素の合成と精製 ジアゾアニリンと 1-ナ フトールのアルカリ性カップリング反応生成物を $2 \%$ 水酸化ナト

*1 この報文を「1-ナフトール類をアゾ成分とするカップリン グ反応に関する研究（第 2 報)」とする.

*2 Satoshi Kishimoto, Tsuneaki Hirashima, Osamu MANABE, Hachiro HIYAMA 大阪市立工業研究所 : 大阪 市北区北扇町.

1) Th. Zinke, H. Bindewald, Ber., 17, 3030 (1884).

2) Th. Zinke, H. Bindewald, Ber., 17, 3026 (1884).
リウム水溶液で 3 回可溶分を除去後, クロロホルムとェチルアル コールの混合溶液から 2 回再結晶して純粋な 2,4 -ビス体色素 $\{$ 分 析値 : $\mathrm{C}=74.8 \%, \mathrm{H}=4.6 \%, \mathrm{~N}=15.7 \%$ (計算値 : $\mathrm{C}=75.0 \%$, $\mathrm{H}=4.6 \%, \mathrm{~N}=15.9 \%$ ) \}, $\mathrm{mp} 193^{\circ} \mathrm{C}$ を得た。

\section{$2 \cdot 2$ 検量線の作製}

2-体，4-体扰よび 2,4-ビス体色素の $0.01 \mathrm{~N} \mathrm{NaOH} \mathrm{50 \% （Vol}$ \%) ピリジン水溶夜中での可視 (紫外) 吸収スペクトルは図 1 で, 定量には 2-体拈よび 4-体色素の極大吸収である $510 \mathrm{~m} \mu$ の波長, ならびに $600 \mathrm{~m} \mu$ の波長を用いた。

な拉，主成分である 4-体色素の吸収スペクトルの影響で 2,4ミビス体色素の極大吸收波長である $565 \mathrm{~m} \mu$ より $600 \mathrm{~m} \mu$ を用いる 方が誤差が小さいことが予備実験より判明した。

2.2.1 2-体色素の検量線式 2.1.1 で精製 した 2-体色素の $50 \%$ ピリジン水溶液中での検量線の式は（1）式のようになるが, ペーパークロマトグラフィーでの回収率は 75〜85\% となり，か

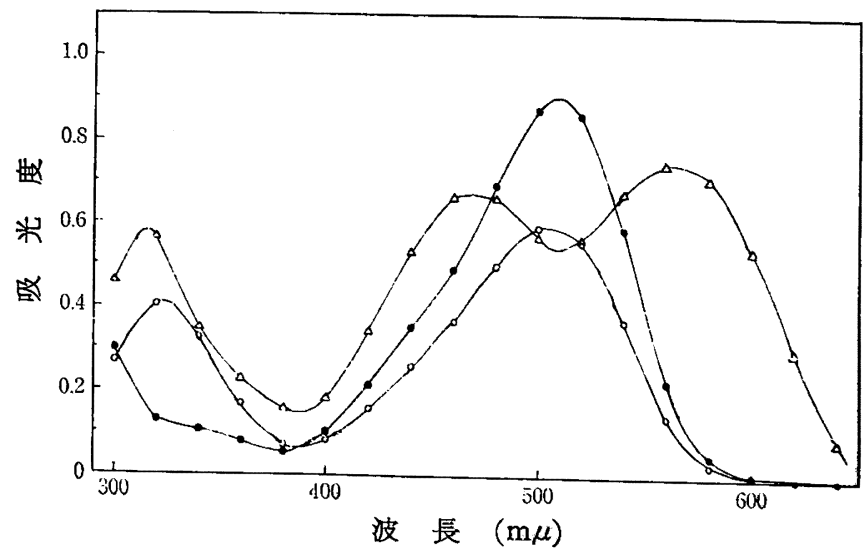

図 12 2-体色素（一O-: $\left.3 \times 10^{-5} \mathrm{~mol} / \mathrm{l}\right) ， 4$-体色素（一-－：

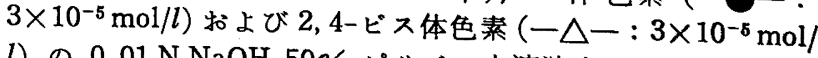
l) の $0.01 \mathrm{~N} \mathrm{NaOH} 50 \%$ ピリシン水溶液中での吸収スペク トル 